\title{
NOTES ON SOME LOWER PALAEOZOIC TO TERTIARY FAUNAS FROM EASTERN NORTH GREENLAND
}

\author{
John S. Peel, Peter R. Dawes and Johannes C. Troelsen
}

The north-east 'corner' of Greenland is geologically probably the least known region in North Greenland. Various expeditions have visited the coastal parts but geological detail, particularly faunal information, has remained surprisingly scarce. Initial field work by Koch (1923, 1925) and Troelsen (1949a, b, 1950) showed that a Precambrian to Silurian section - unfolded in the south, folded in the north - was unconformably overlain by a Carboniferous to Tertiary section, now referred to as the Wandel Sea basin (Dawes \& Soper, 1973).

In preparation for forthcoming field work across North Greenland, fossils and rocks collected mainly by Lauge Koch (1916-1923) and by the Danish Peary Land Expedition (1947-50) in western and eastern North Greenland respectively, have been examined by J.S.P. and P.R.D. Of particular interest are samples collected by J. C. Troelsen and Eigil Knuth in eastern Peary Land, the Prinsesse Øer and in northern Kronprins Christian Land around Station Nord, which supply important additional information about the age of the Lower Palaeozoic and

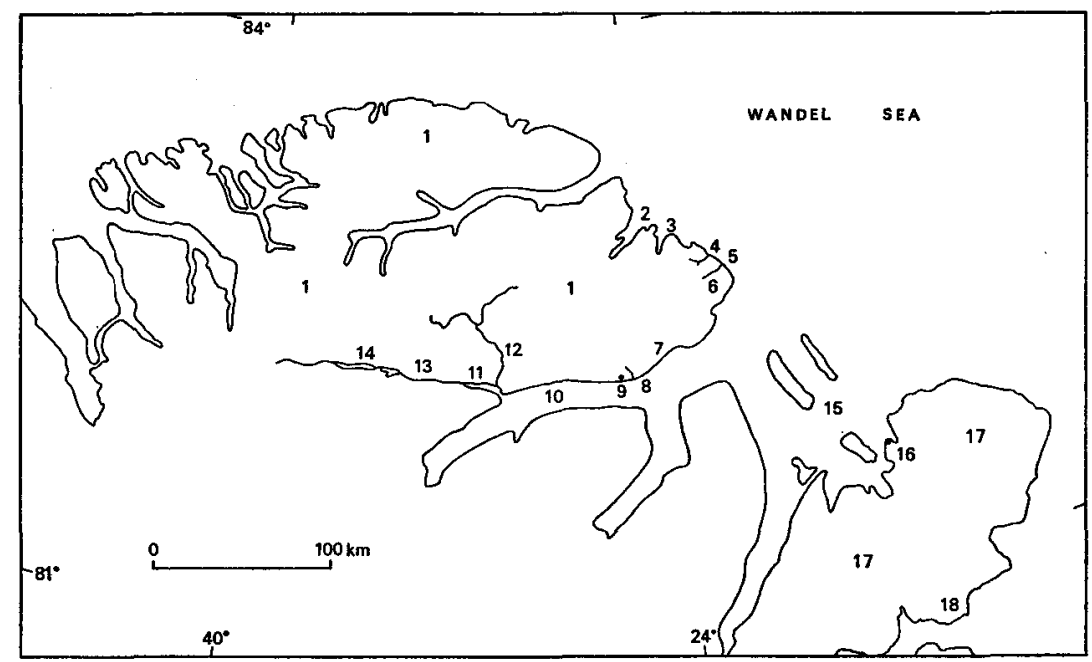

Fig. 3. Toponymic map of eastern North Greenland. Inland Ice and ice fields are not shown. 1, Peary Land; 2, G. B. Schley Fjord; 3, Hellefiskefjord; 4, Foldedal; 5, 'Store Kløft; 6, Herlufsholm Strand; 7, Kjovesletten; 8, Graptolit Elv; 9, Kap Caroline Marie; 10, Independence Fjord; 11, Jørgen Brønlund Fjord; 12, Børglum Elv; 13, Wandel Dal; 14, Midsommersøerne; 15, Prinsesse $\emptyset$ er, Thyra $\emptyset$ is the largest island; 16, Station Nord; 17, Kronprins Christian Land; 18, Amdrup Land. 
Wandel Sea basin strata. This note draws attention to the several small, but stratigraphically significant collections of fossils contained within this material, most details of which have hitherto been unpublished.

\section{Cambrian - Brønlund Fjord Dolomite}

Troelsen (1956) reported olenellid trilobite fragments and Salterella from thin sheets of dark phosphorite in the lower part of the Bronlund Fjord Dolomite, along the northern side of the western end of Midsommerøerne. 17 samples from this locality are present in the collection and consist of loose-lying blocks of dolomite with a rich fauna:

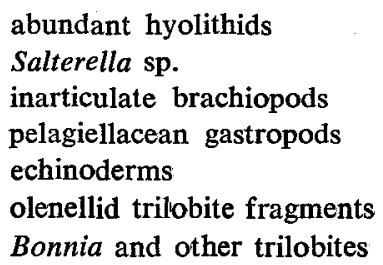

The fauna suggests a late Lower Cambrian age which is in accordance with the description of a fauna of similar age (Poulsen, in press) from shales of the Buen Formation immediately underlying the Brønlund Fjord Dolomite at the mouth of Børglum Elv. Poulsen (op. cit.) also describes Olenellus cf. O. svalbardensis in collections made by J.C. T. from a small island at the mouth of G. B. Schley Fjord.

\section{Ordovician - Wandel Valley Limestone}

Six collections are present from the Wandel Valley Limestone as exposed in the valley of the Børglum Elv, northern side of Jørgen Brønlund Fjord. These take the form of residues, after acid digestion, of silicified fossils and a number of large untreated blocks of dolomitic limestone containing silicified fossils. A faunal list has already been published (Troelsen, 1949a). Gastropods are dominant, with Ceratopea spp. indicating an early Ordovician age for at least the lower and middle parts of the formation. The presence of Ceratopea, abundantly represented by the characteristic, horn-shaped opercula, is particularly noteworthy in view of the recently increased realisation of its potential for correlation (Yochelson \& Bridge, 1957). Specimens are now known to occur across the U.S.A., in Newfoundland, North Greenland, Spitsbergen, central East Greenland and Scotland (Yochelson, 1964) and promise to be very useful in comparing North Greenland strata with key Ordovician sections in these areas. 
Ordovician - B $\phi$ rglum River Limestone

Although J. C. T. collected a number of specimens from this formation in 1948 -49 , only two specimens have been found in the collection, viz, a large colony of Catenipora and the remains of a silicified macluritid gastropod crushed in packing. However, field identifications by J. C. T. include Halysites, Receptaculites, Gonioceras, 'Syringopora' and solitary corals from the formation as exposed in the lower reaches of the valley of the Børglum Elv, suggesting a possible correlation with the Ordovician Gonioceras Bay and Cape Calhoun Formations of western North Greenland. Favosites, Halysites and sponges? are also recorded from a locality some $25 \mathrm{~km}$ upstream of the mouth of the Børglum Elv. Favosites is not known to occur in the Cape Calhoun or Gonioceras Bay Formations (Troedsson, 1928) but is present in seemingly slightly younger, late Ordovician strata in northern Hall Land. In addition, the Børglum River Limestone is recognisable in the G. B. Schley Fjord area where solitary corals, crinoid remains and Halysites were noted in the field by J. C. T.

\section{Silurian - Kjoveslette Sandstones}

Seven samples of grey, micaceous, fine-grained sandstone contain poor impressions of several species of Monograptus, including Monograptus sp. of $M$. priodon type suggestive of a Lower to Middle Silurian age. The sandstone occurred in large, loose slabs in marine post-glacial deposits exposed to the west of Kjovesletten, about $10 \mathrm{~km}$ from the coast. This is the same general locality as Koch's (1923) "East of Cape Caroline Marie" where several pieces of sandy shale collected from river gravels yielded Monograptus priodon? The river was accordingly named 'Graptolit Elv' by Koch.

Similar sandstones are found in situ in many places in central Peary Land north of Independence Fjord stratigraphically higher than the Børglum River Limestone. Previous reference to the Kjoveslette Sandstones is confined to a brief comment in Fränkl (1956) although both Koch (1923) and Troelsen (1956) include the graptolite-bearing Silurian strata on sketch maps.

\section{Carboniferous - Permian}

Brief comments about Carboniferous - Permian strata in eastern Peary Land have been given by Koch $(1923,1925,1929)$ and Troelsen (1949b, 1950). Koch's original fossil collection of 35 samples from the Herlufsholm Strand area which included Fenestrella, crinoids, several corals and productid and spiriferid brachiopods, had to be abandoned on the edge of the Inland Ice in 1921 (Koch, 1929, p. 84).

The present collection contains about 70 Carboniferous - Permian fossiliferous samples from four main localities.

(1) In Hellefiskefjord a section at least $380 \mathrm{~m}$ thick is composed of a lower 
(at least $80 \mathrm{~m}$ ) section of grey-weathering fusulinid limestone, grey and reddish chert, violet shales and shaly limestone and marls, and an upper (at least $230 \mathrm{~m}$ ) unit of grey, brown-weathering, thin-bedded limestone with layers of grey chert. The lower unit (which J. C. T. provisionally referred in the field to the Canyon Fjord Formation of Ellesmere Island) contains abundant fusulinids, solitary corals, crinoids, bryozoans, echinoderms, Syringopora sp., and productid and spiriferid brachiopods. Troelsen (1950) has referred this unit to the late Pennsylvanian (Triticites).

The fauna of the upper unit includes abundant brachiopods (productids, spiriferids, rhychonellids, terebratulids) as well as solitary and colonial corals, bryozoans and gastropods. Of particular interest here is the presence of Athyris amdrupi in the middle of the unit which, as zone fossil of the upper part of the Upper Marine Group in Amdrup Land to the south (Dunbar, 1962), suggests a Lower Permian age. At the top of the exposed section large spiriferids comparable to Spirifer striato-paradoxus Toula Dunbar occur. This species is known from the Upper Permian elsewhere in eastern Peary Land (see below) and from the Upper Permian of East Greenland (Dunbar, 1955), suggesting that the Hellefiskefjord section also reaches into the Upper Permian.

(2) Grey limestone with chert also outcrops on the south side of Foldedal where bryozoans, brachiopods (Derbyia, Athyris, Camarophoria), single corals and gastropods indicate a Permian age.

(3) Large samples of richly fossiliferous, often silicified, limestone collected in 1954 by J. C. T. and Eigil Knuth, south of Station Nord Kronprins Christian Land, contain abundant bryozoans, with some brachiopods, gastropods and corals. These limestones are similar to rocks collected in 1969 by P. R. D., the fauna of which includes Malonophyllum sp., Fenestrelina sp. and Polypora sp. indicative of a Permian, perhaps Lower Permian age (Christian Poulsen, personal communication).

(4) At the coast immediately north of Foldedal a shallow dipping succession is composed of very coarse conglomerate with dark red sandstone layers, dark brown sandy shales and sandstone with conglomerate layers, and some grey-red and violet limestone with sandstone and fine conglomerate beds. The fauna from this section includes solitary and colonial corals, gastropods, crinoids, echinoderms, and productid and spiriferid brachiopods.

The lithology of this succession is strikingly similar to the $200 \mathrm{~m}$ clastic sequence discovered by W. E. Davies (personal communication) in 1961, somewhat south of the present locality, and which has yielded an Upper Permian brachiopod-bryozoan fauna, including Spirifer cf. S. striato-paradoxus Toula.

\section{Triassic}

Details of a $630^{+} \mathrm{m}$ Lower and Middle Triassic section at 'Store Kløft' in eastern Peary Land have been given in Kummel (1953). In addition to the 
ammonite-brachiopod-bivalve fauna mentioned in that paper, the presence of fish remains correlatable with the Scythian fish horizon of Spitsbergen was reported.

This latter material consists of 13 samples collected between 170 and $200 \mathrm{~m}$, in grey to brownish grey shale and fine-grained micaceous sandstone containing some nodules. The vertebrate remains are mainly scattered scales, bones and teeth of selachians and palaeoniscoids (S. E. Bendix-Almgreen, personal communication) although a reptilian vertebra is present.

A few pieces of grey micaceous shale with plant remains are also in the collection.

\section{Cretaceous-Tertiary}

Mention of strata of this age in eastern Peary Land has been restricted to very brief comments by Troelsen (1949a, 1950, 1956). On the south side of Foldedal a gently-folded succession is exposed, comprising black shale and grey sandstone, and greywacke with some very thin conglomeratic layers containing well-rounded quartz pebbles. The black shales commonly display poorly preserved deciduous stem and leaf impressions while the sandstone contains well-preserved specimens of fossil wood. One sandstone bed noted by J.C. T. in this section contained a tree trunk about $1 \mathrm{~m}$ long and $15 \mathrm{~cm}$ in diameter.

Three samples from Foldedal exist in the collection, two are grey sandstone with impressions of stems, the third is a piece of well-preserved fossil wood.

Rocks of similar age form the Prinsesse Øer where a well-exposed section on the west side of Thyra $\varnothing$ contains thin coal seams and black shales with leaf impressions (Eigil Knuth, personal communication). Two samples of poor quality coal collected by Knuth are present in the collection, both having poorly preserved plant remains.

\section{References}

Dawes, P. R. \& Soper, N. J. 1973: Pre-Quaternary history of North Greenland. Mem. Amer. Ass. Petrol. Geol. 19, 117-134.

Dunbar, C. O. 1955: Permian brachiopod faunas of Central East Greenland. Meddr Grønland 110, 3, $169 \mathrm{pp}$.

Dunbar, C. O. 1962: Faunas and correlation of the late Paleozoic rocks of Northeast Greenland. Part III Brachiopoda. Meddr Grønland 167, 6, 14 pp.

Fränkl, E. 1956: Some remarks on the Caledonian mountain chain of East Greenland. Meddr Grønland 103, 11, 43 pp.

Koch, L. 1923: Preliminary report upon the geology of Peary Land, Arctic Greenland. Am. J. Sci., 5th Ser. 5, 189-199.

Koch, L. 1925: The geology of North Greenland. Am. J. Sci., 5th Ser. 9, 271-285.

Koch, L. 1929: The geology of East Greenland. Meddr Grønland 73, 1 Afd. 1, 204 pp.

Kummel, B. 1953: Middle Triassic ammonites from Peary Land. Meddr Grønland 127, 1, $21 \mathrm{pp}$. 
Poulsen, V. (in press): Olenellacean trilobites from eastern North Greenland. Bull. geol. Soc. Denmark.

Troedsson, G. T. 1928: On the Middle and Upper Ordovician Faunas of Northern Greenland. Part II. Meddr Grønland 72, 1, 197 pp.

Troelsen, J. C. 1949a: Contributions to the geology of the area round Jørgen Brønlunds Fjord, Peary Land, North Greenland. Meddr Grønland, 149, 2, 29 pp.

Troelsen, J. C. 1949b: Geologiske undersøgelser i Peary Land 1948-49. Meddr dansk geol. Foren. 11, 501 only.

Troelsen, J. [C.] 1950: Geology. In Winther, P. C. et al. A preliminary account of the Danish Pearyland Expedition, 1948-49. Arctic 3, 6-8.

Troelsen, J. C. 1956: The Cambrian of North Greenland and Ellesmere Island. In El sistema Cámbrico, su paleogeografía y el problema de su base. 20 Congr. geol. int. México. Symp. 3, t. 1, 71-90.

Yochelson, E. L. 1964: The early Ordovician gastropod Ceratopea from East Greenland. Meddr Grønland 164, 7, 12 pp.

Yochelson, E. L. \& Bridge, J. 1957: The Lower Ordovician gastropod Ceratopea. Prof. Pap. U.S. geol. Survey 294-H, 281-302.

J.C.T.

Petrobras,

Caixa Postal 1454,

40.000 Salvador-Bahia,

Brazil.

\section{GEOLOGICAL AND GEOPHYSICAL WORK BETWEEN $69^{\circ} \mathrm{N}$ AND $72^{\circ} \mathrm{N}$, CENTRAL WEST GREENLAND}

\section{Elmar J. Schiener}

In continuation of the programme of geological and geophysical work on the Cretaceous-Tertiary sedimentary and volcanic rocks initiated in 1971 (Henderson, 1972, 1973; GGU, 1973) four groups operated in the area.

Three geologists, three geophysicists, one civil engineer and three assistants formed the core of the various groups. Greenland helpers were employed for shorter periods either as boatmen or bearers. Two groups were involved in mapping and detailed sampling of the Tertiary basalts, one on Nûgssuaq, the second on Ubekendt Ejland. One group studied sedimentological problems in the Cretaceous-Tertiary rocks throughout the whole of the region. Special photogrammetric control studies were carried out by one person attached to different groups (Dueholm, this report). The geophysical party mainly investigated selected areas from south Nûgssuaq to south Svartenhuk Halvø.

The GGU ship K. J.V. Steenstrup with Andreas Viðstein as skipper provided logistic support. 